\title{
EFECTIVIDAD DEL LÁSER DE BAJA INTENSIDAD EN EL CONTROL DE LA HIPERSENSIBILIDAD DENTINARIA
}

\section{EFFECTIVENESS OF LOW INTENSITY LASER IN THE CONTROL OF DENTINE HYPERSENSITIVITY}

\author{
Nadia Gomez ${ }^{1}$, Karen Garcia ${ }^{1}$, Helen de Herrera ${ }^{2}$ y Henry Herrera ${ }^{3}$
}

\section{RESUMEN}

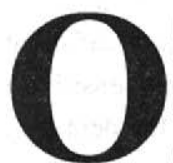

bjetivo

Determinar la efectividad del Láser de baja intensidad para controlar la hipersensibilidad dentinaria.

\section{Métodos}

La presente investigación clínica experimental, se realizó en la Escuela de Postgrado de Odontología de la Universidad Evangélica de El Salvador, se estudiaron 49 piezas dentales permanentes de pacientes entre 22-27 años, que respondían de forma positiva a las pruebas de sensibilidad al frío, calor, ácido y dulce por un máximo de 5 segundos, realizando laserterapia con intervalos de una semana, durante un mes.

\section{Resultados}

La Láserterapia disminuyó la hipersensibilidad inicial al compararla con la final en cuanto al tiempo de duración (inicial: 2.32, final: 0.32 ), el tiempo de reacción (inicial: 0.84 y final: 0.36 ) y la escala análoga visual (inicial: 3.14 y final: $1.53)$.

\section{Conclusiones}

El Láser de baja intensidad demostró ser efectivo, ya que entre la hipersensibilidad inicial y la final, la disminución fue estadisticamente significativa

\section{PALABRAS CLAVE:}

Láser de baja intensidad, Efectividad e Hipersensibilidad dentinaria.

\author{
ABSTRACT

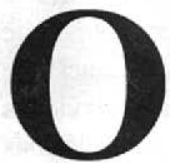 \\ bjective \\ To determine the effectiveness of low intensity \\ laser in the control of dentine hypersensitivity.

\section{Methods}

This clinical experimental research was done in the Postgraduate Department of the Dental School at the Evangelical University of El Salvador. 49 permanent teeth were evaluated in patients with ages between 22 to 27 testing positive to cold, heat, acid and sweet stimulation for a maximum of 5 seconds applying low intensity laser therapy in intervals of a week for a period of one month.

\section{Results}

Low intensity laser therapy reduced initial hypersensitivity when compared to final, in terms of duration (initial: 2.32, final: 0.32 ), reaction time (initial: 0.84 final: 0.36 ) and analog visual scale (initial: 3.14 y final: 1.53 ).

\section{Conclusion}

Low intensity laser proved to be effective as it showed a statistically significant reduction between initial and final dentine hypersensitivity

\section{KEY WORDS:}

Low intensity laser, effectiveness, dentin hypersensitivity.

1. Estudiantes posgrado Operatoria Dental, Universidad Evangélica de El Salvador (Postgraduate student Aesthetic Dentistry Universidad Evangélica de El Salvador)

2. Profesor posgrado Odontología. Universidad Evangélica de El Salvador (DDS. MSc. Postgraduate Professor Universidad Evangélica de El Salvador) 3. Profesor y Director Escuela Posgrado Odontología Universidad Evangélica de El Salvador (DDS. MSc. Postgraduate Director and Professor, UEES) 


\section{INTRODUCCIÓN}

La hipersensibilidad dentinaria se define como "un dolor breve y agudo que se origina en la dentina expuesta como respuesta a los estímulos típicos como los térmicos, evaporativos, táctiles, osmóticos o químicos que no pueden ser atribuidos a otra patología dental" (1).

Paraentender la terminología delahipersensibilidaddentinaria es importante conocer cuales son los elementos estructurales, anatómicos y funcionales que están relacionados con este concepto. La dentina es considerada el eje estructural de la pieza dental con mayor volumen de tejido mineralizado del total del elemento dental; siendo constituida por túbulos dentinarios, que hacen permeable la dentina, ofreciendo una vía de penetración de los agentes irritantes externos para la pulpa(2). Otras diferentes teorías sobre los mecanismos de la hipersensibilidad dentinaria mencionan "la existencia de inervación directa para la dentina"; "los receptores nerviosos odontoblásticos" y la "Teoría Hidrodinámica" que es la mas aceptada y fue propuesta por Brandstrom y Astrom en 1963. Esta última explica que el líquido presente en el interior de los canalículos dentinarios puede moverse rápidamente de adentro hacia afuera produciendo presión sobre las terminaciones nerviosas del Plexo de Raschkow, iniciando un impulso doloroso (3); que se clasifica comoHipersensibilidad dentinaria primaria o esencial en la cual interfieren factores anatómicos, predisponentes, somáticos o psíquicos desconocidos que influencian en el dolor dentinario. En este tipo de dolor no se reportan intervenciones terapéuticas previas como en la Hipersensibilidad dentinaria secundaria, en la cual los sintomas son semejantes o tambien las causas son diversas, pero siempre acompañadas de una intervención previa o por una patología dental. De acuerdo a esa clasificación, surgen las diferentes alternativas de tratamiento que incluyen desde el control domestico con las pastas desensibilizantes, los enjuagatorios con fluorato, los geles desensibilizantes y para los casos mas graves las restauraciones de resina composita, de amalgama, ionómeros de vidrio, iontoforesis, injerto de tejido blando y actualmente la Láser terapia (5).

La Laserterapia, (Luz amplificada por la estimulación de la radiación emitida) es una alternativa que presenta indicios desde la época de los Griegos y Romanos, en la cual la luz se utilizaba como método de tratamiento, siendo sugerida la teoria del láser por primera vez en 1957, por los científicos americanos Charles Townes y Arthur Schawlow (5).

\section{INTRODUCTION}

"Dentine hypersensitivity is defined as a short, sharp pain arising from exposed dentine in response to tipical stimuli as thermal, evaporative, tactile, osmotic or chemical and which cannot be attributed to any other dental pathology"(1).

In order to understand the terminology of dentine hypersensitivity it is important to know the anatomical, structural and functional elements involved within this concept. Dentin is considered the structural axis of the tooth having the highest volume of mineralized dental tissue of the total element; it is constituted by dentin tubules which makes dentin permeable offering a way of penetration for external irritant agents to the pulp (2). Many different theories about mechanisms of dentine hypersensitivity mention "the existence of direct innervations to the dentine"; "the odontoblastic nerve receptors" and the "hydrodynamic theory" this being the most accepted proposed by Brandstrom and Astrom in 1963. This theory explained that the liquid inside the dentinal canaliculi moves rapidily from inside out causing pressure on nerve endings of the Raschkow plexus initiating the pain impulse(3); classified as primary or essential dentin hypersensitivity and influenced by anatomical, somatic or psychological predisposal factors. There is no history of previous interventional therapy in this type of pain nor as in secondary dentin hypersensitivity where similar symptoms are present but a previous pathology or intervention is always present. According to this classification there are different alternatives for treatment including: domestic control with desensitizing toothpaste, mouthwashes containing fluoride and desensitizing gels, in more severe cases resin, amalgam and glass ionomer restorations, iontoforesis, soft tissue grafts and low laser therapy that is actually being used (5).

Laser therapy (Amplified Light by Stimulation of Emitted Radiation) is an alternative treatment that shows its origins since the age of Romans and Greeks, when light was used as a form of treatment, and was suggested for those first time in 1957, by the american scientists Charles Tornes and Arthurs Schawlow (5). 
Los efectos biológicos comprueban que la estimulación con láser de baja intensidad activa la producción de ATP's que ayudan en la multiplicación de las fibras colágenas, formación de enzimas específicas, estimulación del sistema linfático, desarrollo de nuevos vasos sanguíneos (micro circulación), aumentando la síntesis de proteínas y DNA. El Láser con características peculiares comocoherencia,monocromaticidad y unidirecionalidad se diferencia totalmente de la luz natural, generando principalmente efectos terapéuticos antiinflamatorios, analgésicos y reparación tisular. Debido a estos efectos, surge la importancia de realizar este estudio con el propósito de determinar la efectividad del Láser de baja intensidad en el control de la Hipersensibilidad dental, ofreciendo respaldo teórico para futuras investigaciones y actualización al profesional en cuanto a la temática investigada, para que este ofrezca al paciente una terapia alternativa para su problema(5).

\section{MÉTODOS}

Los 49elementos dentalespermanentesfueronindividualmente evaluados y clínicamente sometidos a pruebas de sensibilidad dentaria al frío, calor, ácido y dulce; se determinó tambien con la escala análoga visual el grado de dolor o sensibilidad presente, siendo el valor "cero" considerado como ausencia de sensibilidad dolorosa y el 10 como la máxima sensibilidad dolorosa experimentada por el paciente.

En la primera consulta después de la profilaxis de la pieza (Figura 1) y su secado se aplicó la prueba al frío en cervical, con una bolita de algodón con Endo-ice y se registró el tiempo de duración del estímulo, el tiempo de reacción y la sensibilidad según la escala análoga visual; para la prueba del calor se colocó a nivel cervical un instrumento caliente con extremo redondeado y se registró el tiempo de duración del estímulo y la intensidad del dolor; para el ácido se aplicó algodón embebido en limón en la zona y para el dulce un algodón embebido en agua azucarada.

Con un aparato de baja intensidad de la marca Kondortech (Figura 2), se inició la laserterapia (Figura 3) aplicando $2 \mathrm{~J} /$ $\mathrm{cm} 2$ en forma puntual, perpendicular al eje longitudinal del elemento dental a nivel cervical vestibular (Figura 4) y $2 \mathrm{~J} / \mathrm{cm} 2$ en forma de barrido por la zona; utilizando un total $4 \mathrm{~J} / \mathrm{cm} 2$ de emisión continua.

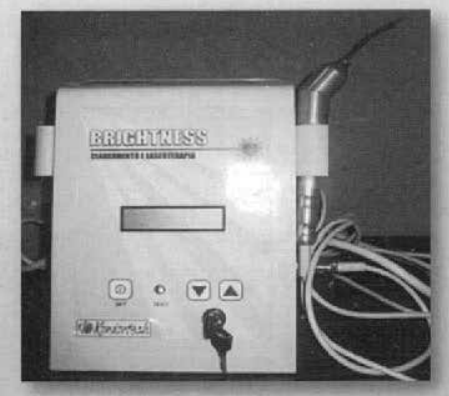

Figura 2- Equipo utilizado, Kondorteck, Brasil. Figure 2-Equipment used in the investigation.
Biological effects prove that stimulation with laser activates the production of ATP, helping the proliferation of collagen fibers, formation of specific enzymes, stimulation of the lymphatic system, development of new blood vessels (micro circulation), increasing the synthesis of proteins and DNA. Laser light with its unique features such as consistency, monochromacity and unidirectionality totally differentiates from natural daylight by generating mainly therapeutic anti-inflammatory, analgesic and tissue repairing effects. For this reasons, this study is important on determining the effectiveness of low intensity laser in the control of dental hypersensitivity as it will provide theoretical support for future researches, upgrade the professional and give patients a new alternative for their problem(5).

\section{METHODS}

Forty nine permanent teeth were individually evaluated and clinically tested for sensitivity responses to heat, cold, acid and sweet; degree of pain and sensitivity was measured with an analog visual scale, where zero was considered total absence of pain and 10 as the maximum pain sensitivity experienced by the patient.

During the first appointment a prophylaxis was made on the selected tooth (Figure 1) after drying it, a cold test was done on the cervical third with a cotton ball containing Endo-Ice.; for the heat test a dental instrument with a round tip previously heated was used; to test acid a cotton was soaked on lemon juice and for sweet a cotton embedded in sugar water. For all tests duration of the stimuli and reaction time was recorded, sensitivity was measured according to analog visual scale.

A low intensity laser equipment from Kondortech Ltda (Figure 2), was used to initiate laser therapy (Figure 3) using $2 \mathrm{~J} / \mathrm{cm} 2$ using a punctual technique, perpendicular to the longitudinal axis of tooth in the cervico-vestibular zone (Figure 4) and $2 \mathrm{~J} /$ $\mathrm{cm} 2$ with a continuous sweep mode using a total of $4 \mathrm{~J} / \mathrm{cm} 2$. 
Figura 4- Aplicación dental puntual, perpendicular al eje longitudinal, a nivel cervical vestibular.

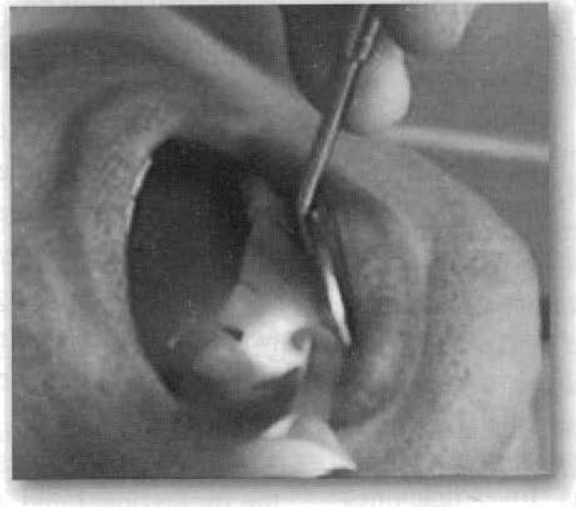

Figure 4- Punctual application technique, perpendicular to the longitudinal axis of the tooth in the cervico-vestibular zone.
En los controles post-operatorios a $\operatorname{los} 7,14$ y 21 días se realizaron las mismas pruebas para registrar los datos en cuanto a sensibilidad dentinaria y posteriormente se aplicaba la Láserterapia ya descrita.

\section{RESULTADOS}

Según el análisis de datos recolectados se elaboraron las siguientes tablas y la grafica 1 .
Post operative controls at 7, 14 and 21 days were made to record dentin sensitivity, low laser therapy was also applied as described before.

\section{RESULTS}

According to analysis of the collected data the following graphics and tables were elaborated.

Tabla 1 - Reacción según estímulo y control.

Table 1 - Reaction according to stimuli and control.

\begin{tabular}{|c|c|c|c|c|}
\hline \multirow{2}{*}{} & \multicolumn{3}{|c|}{ ESTIMULO } & (STIMULI) \\
\hline C & D & A & F & C \\
\hline $1^{\circ}$ & 0.76 & 0.71 & 1.04 & 0.87 \\
\hline $2^{\circ}$ & 0.48 & 0.53 & 1.24 & 0.87 \\
\hline $3^{\circ}$ & 0 & 0 & 0.95 & 0.95 \\
\hline $4^{\circ}$ & 0.06 & 0 & 0.83 & 0.83 \\
\hline
\end{tabular}

Análisis: según el tiempo de reacción en segundos, se observó una disminución para los estímulos dulce ${ }^{(\mathrm{D})}$, ácido ${ }^{(\mathrm{A})}$ y frío ${ }^{(\mathrm{F})}$, pero no para el caliente ${ }^{(C)}$, lo que es bueno, ya que si el tiempo de reacción aumenta o disminuye mucho, eso significaría patología pulpar.
Analysis: According to reaction time in seconds, a reduction for $\operatorname{cold}^{(\mathrm{F})}, \operatorname{acid}^{(\mathrm{A})}$ and sweet ${ }^{(\mathrm{D})}$ stimuli was observed but not for heat, this is considered good in terms that reaction time increases or decreases considerably when a pulpal pathology is present.

Tabla 2 - Duración según estímulo y control.

Table 2 - Duration according to stimuli and control.

\begin{tabular}{|l|c|c|c|c|c|c|}
\hline & \multicolumn{3}{|c|}{ ESTIMULO } & (STIMULI) \\
\hline & C & D & A & F & C \\
\hline & $1^{\circ}$ & 1.67 & 1.97 & 2.85 & 2.79 \\
\hline $2^{\circ}$ & 0.48 & 0.51 & 1.2 & 0.83 \\
\hline $3^{\circ}$ & 0 & 0 & 0.9 & 0.79 \\
\hline $4^{\circ}$ & 0.06 & 0 & 0.79 & 0.44 \\
\hline
\end{tabular}

Análisis: se observó una disminución de la duración del dolor en segundos para todos los estímulos según los diferentes controles.
Analysis: A reduction in duration of pain in seconds was observed for all stimuli in all controls. 
Tabla 3 - Comportamiento de la sensibilidad según control.

Table 3 - Sensitivity behavior according to control.

Análisis: se observó una lisminución de la sensibilidad lolorosa en relación al control ara todos los estímulos según liempo de reacción ${ }^{(\mathrm{TR})}$, tiempo le duración ${ }^{(\mathrm{TD})}$ y la escala náloga visual ${ }^{(\mathrm{EAV})}$.

\begin{tabular}{|c|c|c|c|}
\hline C & TR & TD & EAV \\
\hline $1^{\circ}$ & 0.84 & 2.32 & 3.14 \\
\hline $2^{\circ}$ & 0.78 & 0.76 & 3.21 \\
\hline $3^{\circ}$ & 0.50 & 0.44 & 1.53 \\
\hline $4^{\circ}$ & 0.36 & 0.32 & 1.53 \\
\hline
\end{tabular}

Analysis: A reduction of pain sensitivity in relation to controls was observed according to reaction ${ }^{(\mathrm{TR})}$ and duration ${ }^{(\mathrm{TD})}$ time and Analog Visual Scale ${ }^{(\mathrm{EAV})}$.

Gráfica 1- Sensibilidad según control.

Grafic 1 - Sensitivity according to control.

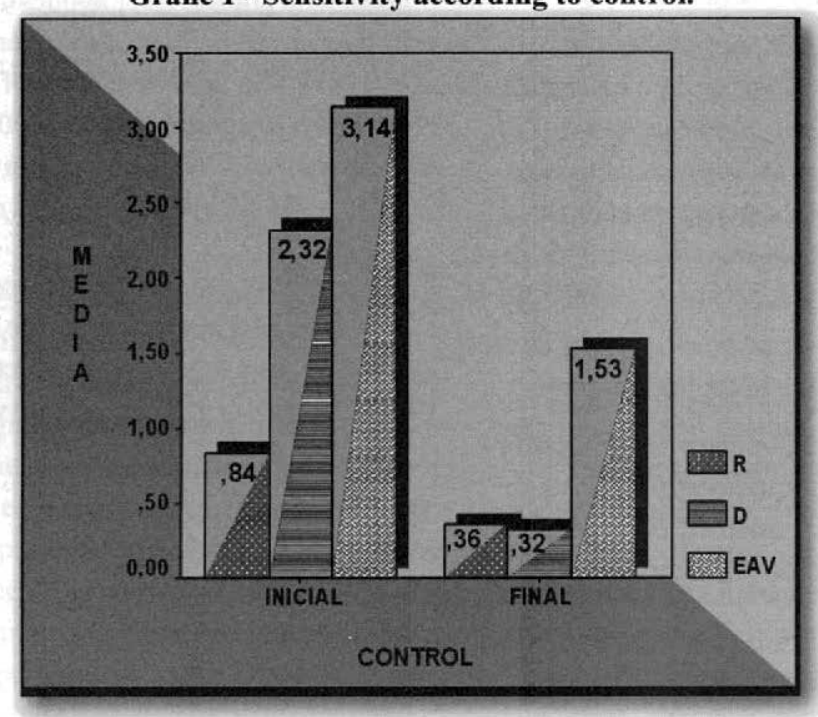

Análisis: se observó una disminución del tiempo de reacción (R), de la duración del dolor (D) y del dolor según la escala análoga visual (EAV), al comparar el control inicial con el final.
Analysis: A reduction of reaction time (R), pain duration (D) and pain according to the Analog Visual Scale (EAV) was observed when comparing initial and final controls.

Tabla 4 - Prueba t de muestras relacionadas

Table 4 - Test for related samples.

\begin{tabular}{|c|c|c|c|}
\hline $\begin{array}{c}\text { PARES } \\
\text { PAIRS }\end{array}$ & $\mathbf{t}$ & gl & $\begin{array}{c}\text { Sig } \\
\text { (bilateral) }\end{array}$ \\
\hline PAR 1 (EAI -EAF) & 13.730 & 48 & .000 \\
\hline PAR 2 (TRI-TRF) & $\mathbf{7 . 6 7 5}$ & 48 & .000 \\
\hline PAR 3(TDI-TDF) & $\mathbf{9 . 9 2 8}$ & 48 & .000 \\
\hline
\end{tabular}

Análisis: Según la significancia bilateral, el grado de libertad y un $95 \%$ de intervalo de confianza, se determinó una disminución significativa entre el tiempo de reacción a los estímulos iniciales (TRI) y finales (TRF), asi como para el tiempo de duración de la sensibilidad (TDI- TDF) y también para los valores obtenidos usando la escala análoga visual (EAI-EAF).
Analysis: According to bilateral significance, degrees of freedom and $95 \%$ of acceptance interval, a significant reduction of time between initial stimuli (TRI) and final stimuli (TRF) was observed, also in sensitivity duration time (TDI-TDF) and in analog visual scale (EAI-EAF) values. 


\section{DISCUSIÓN}

Los resultados del presente estudio demuestran que la Laserterapia, con su efecto analgésico, antiinflamatorio y de regeneración tisular, es un tratamiento eficaz en el control de la sensibilidad dental, disminuyendo en forma estadísticamente significativa el tiempo de duración (inicial: 2.32 , final: 0.32 ) del dolor frente al estímulo, su tiempo de reacción (inicial: 0.84 , final: 0.36 ) y el grado de sensibilidad según la escala análoga visual (inicial: 3.14, final: 1.53); al aplicar $2 \mathrm{~J} / \mathrm{cm} 2$ en forma puntual perpendicular al eje longitudinal del elemento a nivel cervical vestibular y $2 \mathrm{~J} / \mathrm{cm} 2$ en forma de barrido. Es importante recordar que el diagnostico inicial en relación a la etiología de la sensibilidad y de la vitalidad pulpar son factores fundamentales para la indicación de la conducta terapéutica y del éxito del tratamiento.

Estudios con similar metodología de aplicación de la serterapia, pero con diferente verificación de la efectividad, también reportan éxito como el de Matsumoto et al.6 (1985) que con el láser de Helio-Neon, alcanzó un $90 \%$ de efectividad. Brugnera et al. 5(2000) en 1102 piezas, reportan una remisión de la sensibilidad en las cuatro primeras secciones de $85.92 \%$ y en la quinta de $91.27 \%$, siendo que el $8.73 \%$ no respondieron al tratamiento.

Se recomienda que al realizar futuras investigaciones se planifique un mayor número de controles para determinar la recidiva o no de la sensibilidad dental, aumentar la dosis de aplicación para verificar mayor efectividad en el control de la sintomatología e incluir el estudio de las variables genero y edad.

\section{DISCUSSION}

Results of this study show that low laser therapy with its analgesic, anti-inflammatory and tissue regeneration action is an effective treatment in the control of dental sensitivity, with a significant statistic pain reduction in duration time (initial: 2.32, final: 0.32 ) when stimuli was applied, in reaction time (initial: 0.84 , final: 0.36 ) and in sensitivity degree with the Analog Visual Scale (initial: 3.14, final: 1.53 ) applying $2 \mathrm{~J} / \mathrm{cm} 2$ with a punctual technique perpendicular to the longitudinal axis on the cervico-vestibular area of the tooth and $2 \mathrm{~J} / \mathrm{cm} 2$ with a continuous sweep mode. It is important to recall that initial diagnose in relation to ethiology of the sensitivity and pulp vitality are key factors for the indication of therapeutic behavior and treatment success.

Studies with similar laser application methods using different effectiveness tests, have also reported success, Matsumoto et al.6 (1985) who achieved $90 \%$ of effectiveness with HelioNeon laser. Brugnera et al.5 (2000) in 1102 teeth reported a $85.92 \%$ remission of sensitivity in the first four sections and a $91.27 \%$ in the fifth, $8.73 \%$ did not respond to treatment.

It is recommended that further research is planned to carry out more number of controls to determine recurrence of tooth sensitivity, increase the laser dose to verify effectiveness of the symptoms and include the study of gender and age as variables.

\section{REFERENCIAS}

\section{REFERENCES}

1. Kielbasa A., Hipersensibilidad dentinaria: pasos simples para el diagnóstico y tratamiento diario. Internacional Dental Journal 2002, 52: 394-396.

2. Ferraris M. E., Muñoz A. Histología y embriología bucodental. Editorial Panamericana, España, 1999.

3. Mizraji M, et al. Bases neurofisiológicas para el manejo clínico del complejo dentino pulpar. Revista de la Facultad Odontológica de la Universidad Católica del Uruguay. Actas Odontológicas. Año I, Vol I, enero-junio 2004: 15-26.

4. Brugnera Jr, A., Garrini A., Bologna E., Pinhero T. Atlas de Láser terapia aplicada a la Clínica Odontológica. $1^{\text {a }}$ edición, Editoral Santos, Sao Paulo Brasil, 2004 .

5. Brugnera Jr, Zannin F., Gerbi M., Herrera H., Láserterapia en Odontología. Universidad Evangélica de El Salvador 2006.

6. Matsumoto, K. et al. Pathohistologic findings of dental pulp irradied by GAAIAS laser diode. J. Conservated Dent 1985; 28 (4): 1361-65

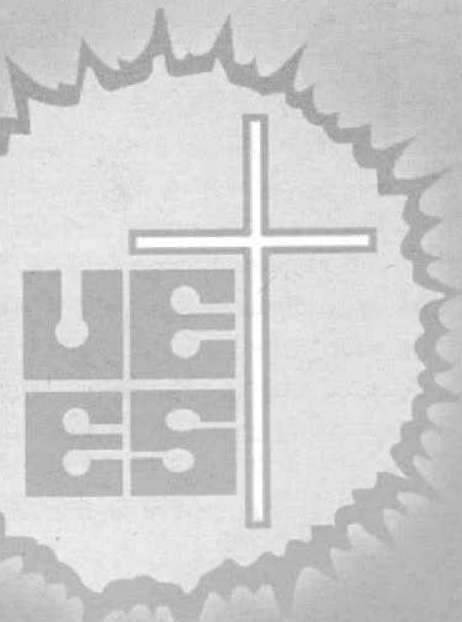

